Research Article

\title{
HE4 has a High Diagnostic Value to Detect Epithelial Ovarian Cancer
}

\author{
$\mathrm{HE}_{4}$ Memiliki Nilai Diagnostik yang Tinggi \\ untuk Mendeteksi Keganasan Ovarium Tipe Epitel
}

\author{
Bismarck J Laihad', Hariyono Winarto', Bambang Sutrisna ${ }^{2}$ \\ ${ }^{1}$ Division of Gynecology Oncology, Department of Obstetrics and Gynecology \\ ${ }^{2}$ Department of Epidemiology \\ Faculty of Medicine University of Indonesia \\ Jakarta
}

\begin{abstract}
Objective: To find out the diagnostic value of CA125 and $\mathrm{HE}_{4}$ as a tumor marker, and also RMI and ROMA as a malignancy predictor in patients with ovarian tumors.

Methods: This study was a diagnostic study using cross-sectional design.This study was performed in Jakarta from November 2010 to May 2011. One hundred and twenty eight serum samples of patients diagnosed with ovarian tumors were collected before undergoing surgery in Dr. Cipto Mangunkusumo General Hospital. The CA125 and $\mathrm{HE}_{4}$ levels were then examined. The histopathological examination of tissue specimens were performed in Department of Pathology Anatomy in RSCM. For statistical analysis, we used a $2 \times 2$ table to produce ROC-AUC curve.
\end{abstract}

Results: The median value of $\mathrm{HE}_{4}$ and $\mathrm{CA} 125$ serum concentrations was higher and more significant on patients with ovarian malignancy than patients with benign ovarian tumor $(\mathrm{p}<0.05)$. Using the cut-off standard, $\mathrm{HE}_{4}$ had the highest accuracy value $(76.5 \%)$. On the premenopausal group, HE4 and ROMA had the same AUC value, that is $85.0 \%$ (95\% CI: 0.73-0.96), whereas on the postmenopausal group, ROMA had the highest AUC value of $96.9 \%$ (95\% CI: 0.921.00).

Conclusion: $\mathrm{HE}_{4}$ has a high diagnostic value as a single tumor marker to detect epithelial ovarian cancer and its combination with CA125 (ROMA) gives an even better result.

[[Indonse J Obstet Gynecol 2013; 1-4: 209-14]

Keywords: epithelial ovarian cancer, human epididymis protein 4, risk of ovarian malignancy algorithm, tumor marker

\begin{abstract}
Abstrak
Tujuan: Untuk menentukan nilai diagnosis penanda tumor CA 125 dan $H E 4$, dan juga RMI dan ROMA sebagai prediktor keganasan pada tumor ovarium.

Metode: Penelitian ini adalah suatu studi diagnostik yang menggunakan metode potong lintang. Sejak November 2010 hingga Mei 2011 terdapat 128 pasien yang didiagnosis tumor ovari di RSCM. Dilakukan pengumpulan serum untuk memeriksa kadar CA125 dan HE4 dari 128 pasien tersebut. Pemeriksaan histopatologi dilakukan oleh Departemen Patologi Anatomi RSCM. Kemudian, data yang didapat diolah dengan analisis tabel $2 \times 2$ dan kurva ROC-AUC.

Hasil: Nilai median dari konsentrasi serum HE4 dan CA125 ditemukan lebih tinggi pada pasien dengan keganasan ovari dibandingkan dengan pasien dengan tumor jinak ovari $(p<0,05)$. Penanda tumor $\mathrm{HE}_{4}$ memiliki nilai akurasi yang tertinggi berdasarkan nilai batas standar. Dalam grup perempuan pre-menopause, $\mathrm{HE}_{4}$ dan ROMA memiliki nilai AUC yang serupa pada 85\% (95\% CI: 0,73-0,96), sedangkan pada grup perempuan post-menopause, ROMA menunjukkan nilai AUC yang tertinggi pada skor 96,9\% (95\% CI: 0,92-1,00).

Kesimpulan: HE4 sebagai sebuah penanda tumor memiliki nilai diagnostik yang tinggi untuk mendeteksi keganasan ovarium tipe epitel, dan kombinasi antara HE4 dan CA125 (ROMA) memberikan hasil yang lebih baik dibandingkan penggunaan satu penanda tumor HE4.

[Maj Obstet Ginekol Indones 2013; 1-4: 209-14]
\end{abstract}

Kata kunci: human epididymis protein 4, kanker ovarium tipe epitel, penanda tumor, risk of ovarian malignancy alogarithm

Correspondence: Bismarck Joel Laihad. Division of Gynecology Oncology, Department of Obstetrics and Gynecology, University of Indonesia. Telephone: 021-3914806, Fax: 021-3914806, Email: bismarcklaihad@gmail.com

\section{INTRODUCTION}

Ovarian cancer is the second most common gynecologic malignancy. In Indonesia, based on the reports from 13 pathology laboratories in 2002, ovarian cancer ranked as the third (829 cases) most common from all malignancy in women, after cervical and breast cancer. In 2012, based on Jakarta cancer registry, ovarian cancer is the third leading female cancer with the incidence 4.27 in 100,000 women. ${ }^{1-4}$
Poor life expectancy in ovarian cancer is due to the lack of early-stage findings, causing most ovarian cancer cases to be found in advanced stages. Until now, there is no single biomarker which could be used to predict ovarian cancer. ${ }^{5}$ CA-125, as one of the most commonly used biomarker in epithelial ovarian cancer (EOC), is detected only in $50-60 \%$ of early-stage epithelial ovarian carcinoma (EOC) patients. ${ }^{6}$ 
Recently, several studies indicated that the combined use of biomarkers such as CA125 and $\mathrm{HE}_{4}$ could improve the sensitivity and specificity of EOC detection. HE 4 serum marker has a high sensitivity to detect an early stage ovarian cancer. Combination of both markers is even more accurate than the use of these markers individually. 5,7

Although there are several scoring systems or methods to predict ovarian malignancy, the definite method has not been established yet. Moore et al introduced a malignancy prediction method known as ROMA (Risk of Ovarian Malignancy Algorithm), which was worked out by combining the results of CA 125 and $\mathrm{HE}_{4}$ examinations. Predictive Probability Index (PPI) of ROMA had an accuracy value up to $93.8 \%{ }^{5,8}$ However, Van Gorp et al (2011) found that $\mathrm{HE}_{4}$ and ROMA were not superior to a single CA125 examination in predicting ovarian malignancy. ${ }^{9}$

Based on the above background, this study aims to compare the diagnostic value of CA125 and $\mathrm{HE}_{4}$ markers, and their combination in Risk Malignancy Index (RMI) and ROMA in predictingthe risk of ovarian malignancy in patients with ovarian tumors before undergoing surgery at Dr. Cipto Mangunkusumo General Hospital (RSCM) in Jakarta, Indonesia.

\section{MATERIALS AND METHODS}

This was a cross sectional study, conducted at RSCM and Prodia Clinic Laboratory Jakarta from November 2010 to May 2011. The research population was all patients who came to RSCM and diagnosed with ovarian tumors and met the inclusion criteria. The inclusion criteria were premenopausal or postmenopausal women, diagnosed as having ovarian tumors through physical examination/gynecology and transvaginal ultrasound, and the tumor was considered respectable. Patients with histopathological result of non-epithelial ovarian tumor, history of oophorectomy, history of previous ovarian cancer treatment, and pregnancy were excluded from the study. Afterwards, blood samples were collected and stored in a $-20^{\circ} \mathrm{C}$ temperature, and were analyzed using ARCHITECT plus i 2000 SR tool which measure the quantity of CA125 and $\mathrm{HE}_{4}$. The pathologist from RSCM then conducted the histopathological analysis of the tissue specimens.
Diagnostic method of pre-surgery patients with pelvic masses for the prediction of ovarian cancer is based on the value of CA-125 serum, ultrasound morphology $(\mathrm{U})$ and menopause status $(\mathrm{M})$. RMI = $\mathrm{U} \times \mathrm{M} \times$ the value of $\mathrm{CA}-125$, where ultrasound score $=1$ if there is no morphological abnormalities or found one, $\mathrm{U}=3$ if found $\geq 2$ morphological picture. Menopause status score is $M=1$ on premenopause and $\mathrm{M}=3$ on post menopause. Score $\geq$ 200 was classified as malignant risk.

ROMA is an algorithm used to predict the risk of ovarian malignancy in patients with pelvic masses, so that patients can be stratified as low risk and high risk based on the value of CA-125 and HE4. Premenopausal women is classified as high risk when the Probability Prediction (PP) is more than $7.4 \%$, while postmenopausal women is classified as high risk when the PP is more than $25.3 \%$.

Data was analyzed using 9.2 Stata program. The statistical analysis aimed to obtain the value of sensitivity, specificity, PPV, NPV, and accuracy. Another analysis on menopausal status and stage of epithelial ovarian cancer using ROC curve was also performed to obtain the value of AUC with 95\% confidence interval calculations,. This study compared the ROC and AUC value of CA125, HE4, RMI and ROMA to the staging method in FIGO, with $\mathrm{p}$ value $<0.05$.

\section{RESULTS}

From November 2010 to May 2011, there were 128 patients at RSCM that met the inclusion and exclusion criteria. From those 128 patients, 61 patients $(47.66 \%)$ had benign ovarian tumor, 50 $(39.06 \%)$ had malignant tumor, and the other 17 were borderline $(13.28 \%)$. From 61 cases of benign ovarian tumors, the most common type was endometriosis (26 cases (42.62\%)), followed by mucinous cystadenoma with 18 cases $(29.51 \%)$, then serous cystadenoma and seromucinous (29.51\% and $4.92 \%)$. For the malignant cases (epithelial ovarian cancer), the most common histological types were serous cystadenocarcinoma 19 cases (38\%), followed by endometrioid with 14 cases (28\%), mucinous with 8 cases (16\%), clear cell with 7 cases (14\%), and carcinosarcoma with 2 cases $(4 \%)$.

There were significant differences between benign and malignant groups on the menopausal status, ultrasound score, CA125 value and $\mathrm{HE}_{4}$ 
Table1. Distribution of Age, Menopausal Status, USG Score, CA125, HE4 on Benign and Malignant Ovarian Tumors

\begin{tabular}{|c|c|c|c|c|}
\hline \multirow{2}{*}{ Variable } & Benign & Malignant & \multirow{2}{*}{$\mathbf{p}$} & \multirow{2}{*}{ Test } \\
\hline & $n=61$ & $n=50$ & & \\
\hline Age (mean) & 41 & 44 & 0.2167 & $\mathrm{t}$ test \\
\hline \multicolumn{5}{|l|}{ Menopausal Status } \\
\hline Premenopause & $44(63.77 \%)$ & $25(36.23 \%)$ & \multirow[t]{2}{*}{0.017} & \multirow[t]{2}{*}{ chi $^{2}$ test } \\
\hline Postmenopause & $17(40.48 \%)$ & $25(59.52 \%)$ & & \\
\hline \multicolumn{5}{|l|}{ USG Score } \\
\hline 0 & $24(96.00 \%)$ & $1(4.00 \%)$ & \multirow[t]{3}{*}{0.000} & \multirow[t]{3}{*}{ chi $^{2}$-test } \\
\hline 1 & $21(67.74 \%)$ & $11(32.26 \%)$ & & \\
\hline $2-5$ & $16(29.09 \%)$ & $45(70.01 \%)$ & & \\
\hline \multicolumn{5}{|l|}{ CA $125(\mathrm{U} / \mathrm{ml})$} \\
\hline Mean & 195.5 & 1763.47 & \multirow[t]{4}{*}{0.000} & \multirow[t]{4}{*}{ U-test } \\
\hline Median & 82.5 & 357.45 & & \\
\hline Minimum & 8.1 & 13.1 & & \\
\hline Maximum & 2441.4 & 9872.3 & & \\
\hline \multicolumn{5}{|l|}{$\mathrm{HE}_{4}(\mathrm{pM})$} \\
\hline Mean & 75.7 & 1338.05 & \multirow[t]{4}{*}{0.000} & \multirow[t]{4}{*}{ U-test } \\
\hline Median & 52.3 & 495.45 & & \\
\hline Minimum & 29.5 & 26.1 & & \\
\hline Maximum & 436.3 & 15000 & & \\
\hline
\end{tabular}

Table 2. Diagnostic Value of CA125, $\mathrm{HE}_{4}, \mathrm{RMI}$ and ROMA based on cut-off Standard

\begin{tabular}{lcccccccc}
\hline \hline \multirow{2}{*}{ Marker } & \multirow{2}{*}{$\begin{array}{c}\text { Cut-off } \\
\text { Standard }\end{array}$} & \multicolumn{7}{c}{ Diagnostic Value } \\
\cline { 3 - 9 } & & Sensitivity & Specificity & PPV & NPV & LR + & LR - & Accuracy \\
\hline HE $_{4}$ & 70 & $90.0 \%$ & $65.6 \%$ & $68.2 \%$ & $88.9 \%$ & 2.61 & 0.15 & $76.5 \%$ \\
CA125 & 35 & $96.0 \%$ & $24.6 \%$ & $51.1 \%$ & $88.2 \%$ & 1.27 & 0.16 & $56.7 \%$ \\
RMI & 200 & $88.0 \%$ & $65.6 \%$ & $67.7 \%$ & $87.0 \%$ & 2.56 & 0.18 & $75.6 \%$ \\
ROMA & $7.4 / 25.3$ & $94.0 \%$ & $42.6 \%$ & $57.3 \%$ & $89.7 \%$ & 1.64 & 0.14 & $65.7 \%$ \\
\hline \hline
\end{tabular}

value. Median value of $\mathrm{HE}_{4}$ and CA125 serum concentration was significantly higher in patients with EOC compared to those with benign ovarian tumor, with $\mathrm{p}$ value $<0.05$ (Table 1 ).

The diagnostic value of sensitivity, specificity, PPV, NPV, positive and negative like hood ratio (LR+ and LR-), as well as accuracy of tumor markers in predicting the ovarian malignancy are presented in Table 2. By using standard cut-off values, $\mathrm{HE}_{4}$ had the highest accuracy value (76.5\%), followed by RMI, ROMA, and the last CA125 at 75.6\%, $65.7 \%$, and $56.7 \%$, respectively.

As can be seen in Figure 1, $\mathrm{HE}_{4}$ and ROMA in the premenopausal group had the same AUC value at $85.0 \%$ (95\% CI: 0.73-0.96), whereas in the postmenopausal group ROMA had a higher AUC value at $96.9 \%$ (95\% CI: 0.92-1.00), followed by $\mathrm{HE}_{4}$ (93.9\%). CA125 and RMI had a same AUC value at 93.6\%. Furthermore, ROMA had the highest AUC value of $90.5 \%$ followed by $\mathrm{HE}_{4}, \mathrm{RMI}$, and CA125 respectively $89.9 \%$, $87.3 \%$, dan $82.0 \%$.

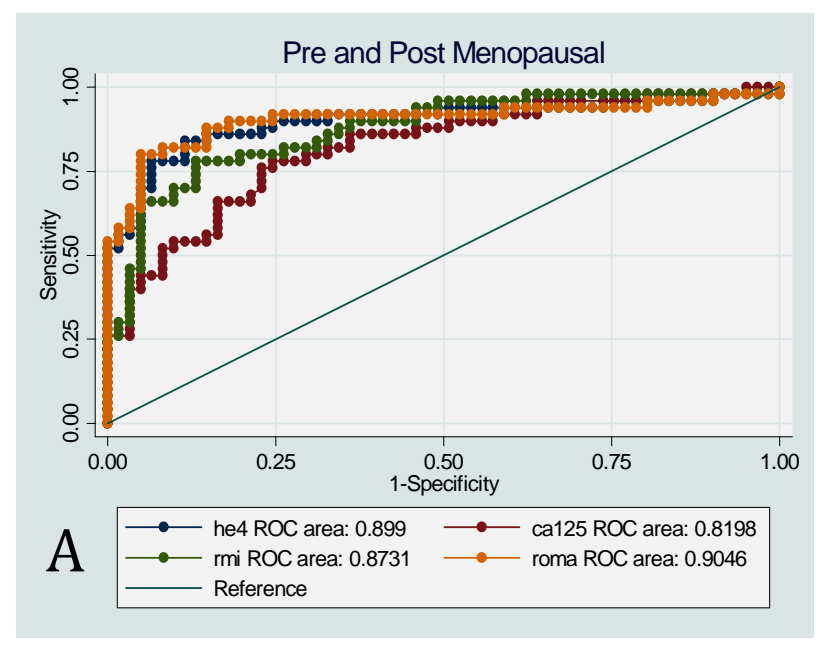

Figure 1. ROC Curve of CA125, HE4, RMI and ROMA based on menopausal status and FIGO stage. (A) Malignant vs Benign on all patients including pre and postmenopause. 


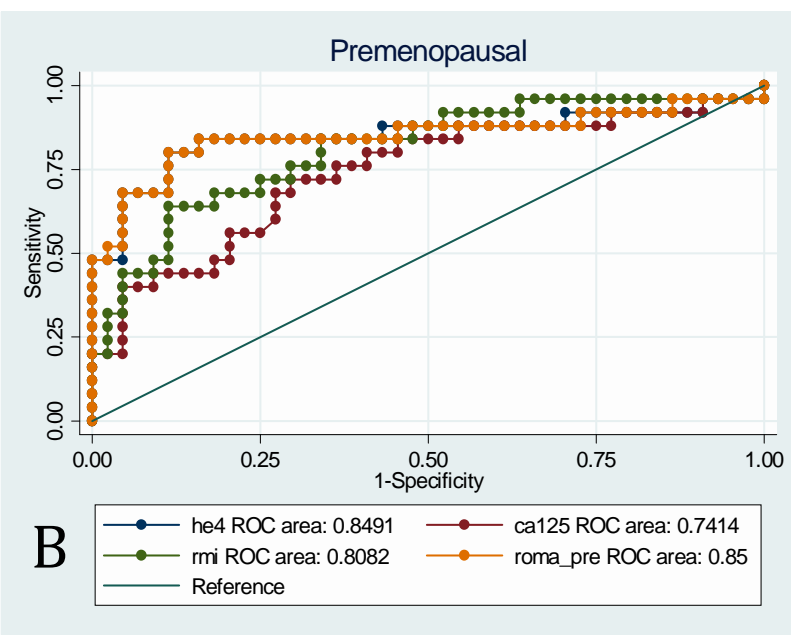

Figure 1. ROC Curve of CA125, HE4, RMI and ROMA based on menopausal status and FIGO stage. (B) Malignant vs Benign on premenopausal patients.

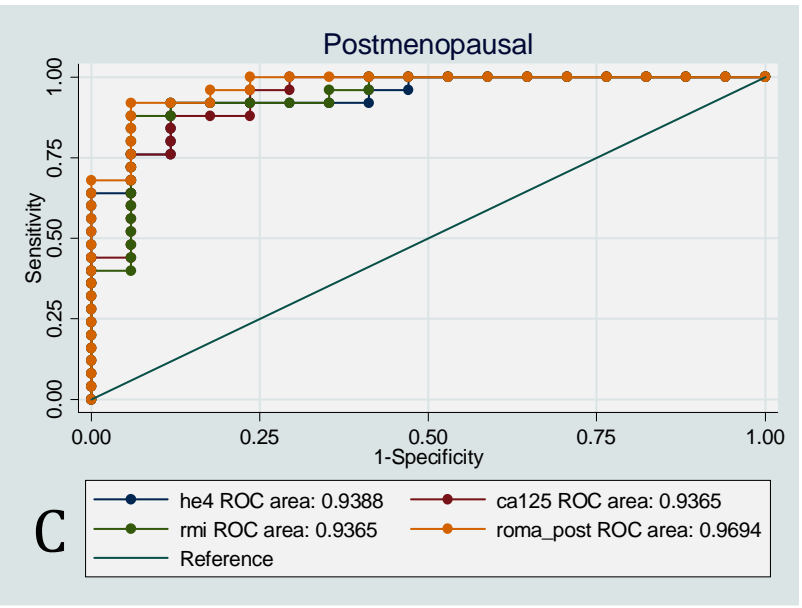

Figure 1. ROC Curve of CA125, HE4, RMI and ROMA based on menopausal status and FIGO stage. (C) Malignant vs Benign on postmenopausal patients.

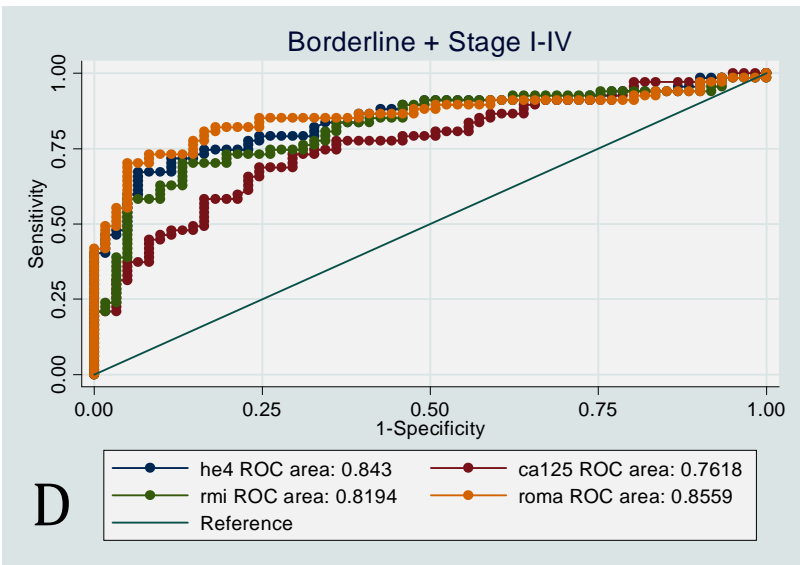

Figure 1. ROC Curve of CA125, HE4, RMI and ROMA based on menopausal status and FIGO stage. (D) Malignant (including borderline) vs Benign on all patients.

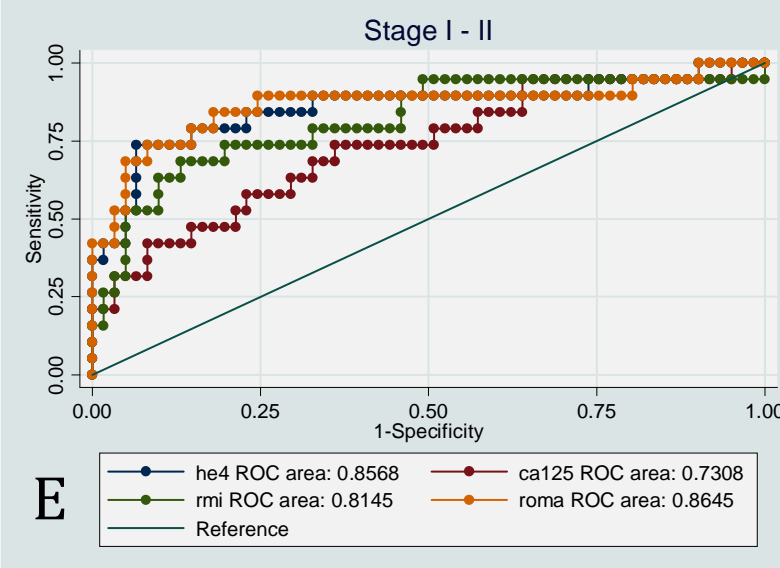

Figure 1. ROC Curve of CA125, $\mathrm{HE}_{4}, \mathrm{RMI}$ and ROMA based on menopausal status and FIGO stage. (E) Malignant vs Benign on stage I-II patients.

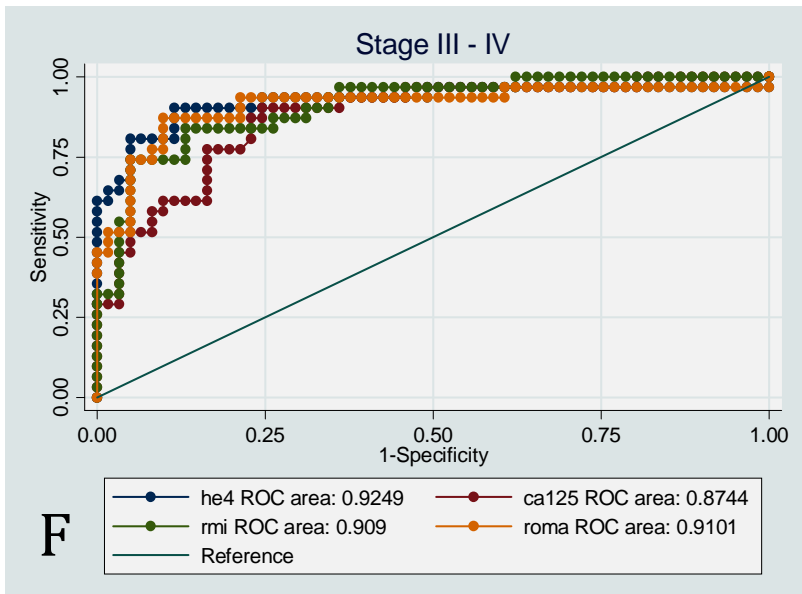

Figure 1. ROC Curve of CA125, HE4, RMI and ROMA based on menopausal status and FIGO stage. (F) Malignant vs Benign on stage III-IV patients.

\section{DISCUSSION}

The sensitivity of CA125 to detect EOC based on the determined cut-off standard $(35 \mathrm{U} / \mathrm{ml})$ was very high, reaching $96 \%$. On the other hand, the specificity value of CA125 was very low (24.6\%); compared to $\mathrm{HE}_{4}$ with sensitivity value of $90 \%$ and $65.6 \%$ specificity value. Hellstrom et al showed that there was no significant difference in sensitivity value of $\mathrm{HE}_{4}$ and $\mathrm{CA} 125$ in differentiating malignant and benign tumor. However, the specificity of $\mathrm{HE}_{4}$ was significantly higher than that of CA125. ${ }^{10}$ The very low value of CA125 specificity on this research was because the mean and median values of CA125 from all benign tumors samples in this research were above the value of cut-off 
standard, as presented on Table 1 . The standard cut-off value for $\mathrm{HE}_{4}$ in this research was $70 \mathrm{~mol} / \mathrm{l}$, based on a study by Moore et al (2008) ${ }^{7}$ and a recommendation of insert KIT ARCHITECT $\mathrm{HE}_{4}$ reagent used in this research.

Holcomb et al, compared the ability of CA125 vs $\mathrm{HE}_{4}$, and concluded that $\mathrm{HE}_{4}$ was more superior in specificity compared to CA125. Similarly, according to Van Gorp et al, $\mathrm{HE}_{4}$ had a higher specificity value than CA125 using the cut-off standard. ${ }^{9,12}$

Several studies on CA125 and $\mathrm{HE}_{4}$ by Moore at al (2008), Huhtinen at al (2009), Nolen et al (2010), Holcomb et al (2011), and Chang et al (2011), stated that a combination of CA125 and $\mathrm{HE}_{4}$ could further improve the diagnostic ability to differentiate malignant and benign tumors among patients with adnexal masses before surgery. Moore at al (2009) introduced ROMA (Risk of Ovarian Malignancy Algorithm), a stratification of risk in women with pelvic masses without involving ultrasound. ROMA is considered more sensitive than RMI and calculated by combining the results of CA125 and $\mathrm{HE}_{4}{ }^{7,8,11-14}$ Using standard cut-off value, $\mathrm{HE}_{4}$ and $\mathrm{RMI}$ are proven to have a higher accuracy value than ROMA and CA125 (Table 2).

The AUC value of $\mathrm{HE}_{4}$ and ROMA is the highest in all patients, both premenopausal group and postmenopausal group, compared to that of RMI and CA125. Montagnana et al also compared the AUC values of $\mathrm{HE}_{4}, \mathrm{CA} 125$, and ROMA on pre and postmenopausal groups, and concluded that $\mathrm{HE}_{4}$ and ROMA showed excellent ability only in the postmenopausal group, but not in the premenopausal group. ${ }^{15}$

In this study, $\mathrm{HE}_{4}$ and ROMA in the premenopausal group have the same AUC value at 85\% (95\% CI: 0.73-0.96). On the other hand, Van Gorp et al's study compared the AUC values among ROMA, HE 4 and CA125, and stated that the ability of $\mathrm{HE}_{4}$ and ROMA was not higher than a single CA125 as tumor marker to predict ovarian malignancy. This was based on the comparison of ROCAUC values in all patients (pre and postmenopause) on ROMA (89.8\%) vs $\mathrm{HE}_{4}(85.7 \%)$ vs CA125 (87.7\%), that after being tested statistically, there were not any significant differences among the three $(p>0,005){ }^{9}$

Advanced stage EOC (Figure 1.E), resulted in higher AUC values for ROMA, HE 4 and RMI than those in early stage (Figure 1. F). This results was supported by Gorp et al, and Moore et al, where the AUC values for ROMA, HE 4 and RMI were higher in advance stage EOC patients than those with early stage disease. ${ }^{11,17}$ Furthermore, CA125 had a low diagnostic value in early stages EOC, as stated by Sasarolidan Moore, where elevated levels of CA125 were only found in $50-60 \%$ of early stage EOC cases. $7,16,17$

After comparing ROMA to RMI in 457 patients, Moore et al found that the AUC for ROMA was significantly higher than RMI in all stages of epithelial ovarian cancer. Moore et al, concluded that ROMA had a higher diagnostic value than RMI clinically and statistically. ${ }^{18}$

This study found that $\mathrm{HE}_{4}$ as a new tumor marker has a higher diagnostic value than CA125. Moreover, when the two are combined, such as in ROMA algorithm, it shows a better ability as a predictor of epithelial ovarian cancer.

\section{CONCLUSION}

$\mathrm{HE}_{4}$ as a single tumor marker has a high diagnostic value in detecting epithelial ovarian malignancy. It has a better specificity and accuracy compared to CA125. However, combination of $\mathrm{HE}_{4}$ and CA125 (ROMA) shows a better ability as ovarian malignancy predictor compared to a single $\mathrm{HE}_{4}$ marker.

\section{CONFLICT OF INTEREST}

The Author has no conflict of interest.

\section{REFERENCES}

1. Aziz MF. Gynecological cancer in Indonesia. J Gynecol Oncol, 2009; 20(1): 8-10.

2. Boyle P, B Levin. World Cancer Report, WHO, Editor. International Agency for Research on Cancer: Switzerland. 2008

3. Hennessy BT, RL Coleman, M. Markman. Ovarian cancer. Lancet, 2009; 374(9698): 1371-82.

4. Wahidin M, Noviani R, Hermawan S et al. Population-based cancer registration in Indonesia. Asian Pac J Cancer Prev. 13(4):1709-10.

5. Havrilesky LJ, Whitehead CM, Rubatt JM et al. Evaluation of biomarker panels for early stage ovarian cancer detection and monitoring for disease recurrence. Gynecol Oncol, 2008; 110(3): 374-82.

6. Rosen DG, Wang LJ, Atkinson N et al. Potential markers that complement expression of CA125 in epithelial ovarian cancer. Gynecol Oncol, 2005; 99(2): 267-77. 
7. Moore RG, Brown AK, Miller CM et al. The use of multiple novel tumor biomarkers for the detection of ovarian carcinoma in patients with a pelvic mass. Gynecol Oncol, 2008; 108(2): 402-8.

8. Moore RG, McMeekin DS, Brown AK et al. A novel multiple marker bioassay utilizing HE4 and CA125 for the prediction of ovarian cancer in patients with a pelvic mass. Gynecol Oncol, 2009; 112(1): 40-6.

9. Van Gorp T, Cadron I, Despierre E et al. HE4 and CA125 as a diagnostic test in ovarian cancer: prospective validation of the Risk of Ovarian Malignancy Algorithm. Br J Cancer, 2011; 104(5): 863-70.

10. Hellstrom I, Raycraft J, Hayden-Ledbetter M et al. The HE4 (WFDC2) protein is a biomarker for ovarian carcinoma. Cancer Res, 2003; 63(13): 3695-700.

11. Chang X, Ye X, Dong L et al. Human epididymis protein 4 (HE4) as a serum tumor biomarker in patients with ovarian carcinoma. Int J Gynecol Cancer. 2011. 21(5): 852-8.

12. Holcomb K, Vucetic Z, Miller MC et al. Human epididymis protein 4 offers superior specificity in the differentiation of benign and malignant adnexal masses in premenopausal women. Am J Obstet Gynecol. 2011. 205(4): 358 e1-6.

13. Huhtinen K, Suvitie P, Hiissa J et al. Serum HE4 concentration differentiates malignant ovarian tumours from ovarian endometriotic cysts. Br J Cancer, 2009; 100(8): 1315-9.
14. Nolen B, Velikhokatnaya L, Marrangoni A et al. Serum biomarker panels for the discrimination of benign from malignant cases in patients with an adnexal mass. Gynecol Oncol. 2011. 117(3): 440-5.

15. Montagnana M, Danese E, Ruzzenente 0 et al. The ROMA (Risk of Ovarian Malignancy Algorithm) for estimating the risk of epithelial ovarian cancer in women presenting with pelvic mass: is it really useful? Clin Chem Lab Med. 2011. 49(3): 521-5.

16. Maharaj AGJI, Menon U. Principles and Practice of Gynecologic Oncology. $5^{\text {th }}$ Ed. Development And Identification Of Tumor Markers, ed. M.M. In Barakat R R, Randall M E. 2009; 145-50.

17. Sasaroli D, G Coukos and N Scholler. Beyond CA125: the coming of age of ovarian cancer biomarkers. Are we there yet? Biomark Med, 2009; 3(3): 275-88.

18. Moore RG, Jabre-Raughley M, Brown AK et al. Comparison of a novel multiple marker assay vs the Risk of Malignancy Index for the prediction of epithelial ovarian cancer in patients with a pelvic mass. Am J Obstet Gynecol, 2010; 203(3): 228 e1-6. 